\title{
STUDI PERBANDINGAN USAHATANI PADI ORGANIK DENGAN ANORGANIK DI DESA SUMBER NGEPOH KECAMATAN LAWANG KABUPATEN MALANG
}

\author{
Muhammad Saikhu \\ Dosen STPP Malang \\ email : musaik09@gmail.com
}

\begin{abstract}
ABSTRAK
Lokasi Penelitian dilaksanakan di Desa Sumber Ngepoh Kecamatan Lawang Kabupaten Malang Propinsi Jawa Timur. Penetapan lokasi dilakukan secara sengaja (purposive), Ada 2 jenis data yang digunakan dalam penelitian ini yaitu data Primer dan sekunder. Sampel penelitian adalah Kelompoktani Sumber Makmur I dan II ??? Data masing-masing usahatani dianalisis dengan menggunakan uji-t dan Chow test analisys. penelitian dilaksan akan hasil penelitian untuk usahatani, Produksi (kw) organik 79,87 dan untuk anorganik 79,84 Total Biaya Rp.6.953.484/organik 5.310.150 /anorganik, Total Penerimaan Rp. 23.962.853/organik dan Rp.21.557.082/anorganik, Total Pendapatan Rp 17.009.369/organi16.439.009/anorganik. . Faktor - faktor produksi diantara variabel Tenaga Kerja (X1), Input Pupuk (X2), Input Benih (X3), dan Pestisida (X4) secara bersama-sama keempat variabel secara signifikan berpengaruh nyata terhadap Produksi (Y) pada budidaya anorganik,sedang pada organik dari ke empat variabel hanya pada Pestisida (X4) berpengaruh sangat nyata terhadap produksi.
\end{abstract}

Kata kunci : organik, anorganik, usahatani, faktor-faktor usahatani

\begin{abstract}
The location of the research was conducted in Sumber Ngepoh Village, Lawang District, Malang Regency of East Java Province. Location determination is done purposively (purposive), There are 2 types of data used in this study the primary and secondary data. The data of each farm is analyzed by using t-test and Chow test analisys. Results for organic production (kw) production 79,87 and for inorganic 79,84 Total Cost Rp 6,953,484 / organic 5,310,150 / inorganic, Total Admission Rp. 23.962.853 / organic and Rp. 21,557,082 / Inorganic, Total Revenue Rp 17.009.369 / organic 16.439.009 / Inorganic The factors that most influence production among Labor variables (X1), Fertilizer Input (X2), Seed Input (X3), and Pesticide (X4) together four variables significantly influence to Production (Y) for medium anorrganic on the organic of the four variables only on Pesticide (X4) have a very significant effect on the production of Chow Test Results F count> F table then it can be concluded that the regression model of organic farming with inorganic is significantly different or in other words the production of both types of farming which is influenced by labor factors, fertilizers, seeds and the use of pesticides is significantly different.
\end{abstract}

Keywords: organic, anorganic, farming, farming factors

\section{PENDAHULUAN}

Peningkatan produksi padi nasional melalui program Intensifikasi dan Ekstensifikasi atau lebih dikenal green revolition(revolusi hijau) diera 70 -an yang bertumpu pada penggunaan sarana produksi berbahan sintetis meninggalkan ketergantungan terhadap sikap dan perilaku petani dalam usahataninya. Di awal pelaksanaan Program Intensifikasi atau Ekstensifikasi yang wajib dilaksanakan 
oleh petani, tidak terkecuali petani di lokasi penelitian memang berhasil meningkatkan produksi, akan tetapi dalam beberapa tahun berikutnya program tersebut dirasa merugikan dibandingkan sebelum masa revolusi hijau. Sebelumnya petani hanya menggunakan sisa tumbuhan atau ternak untuk kebutuhan pupuk di sawahnya, setelah pencanangan program revolusi hijau, petani tergantung kepada perusahaan penghasil pupuk anorganik. Dua hal yang sangat dirasakan oleh petani dalam pelaksanaan sistem pertanian intensif yaitu :

\section{Dampak Ekonomi}

Adanya peningkatan biaya produksi dalam rangka pembelian pupuk buatan, dimana jumlahnya semakin bertambah dalam setiap masa produksi untuk mempertahankan tingkat kesuburan tanahnya, dan harga pupuk yang terus naik, juga kebutuhan untuk pestisida karena peledakan populasi hama/penyakit, harga jual gabah cenderung rendah apalagi pada saat panen raya.

\section{Dampak Ekologi}

Adanya penurunan kualitas lingkungan yang ditandai dengan hilangnya musuh alami (predator) bagi beberapa hama penyakit akibat dari penggunaan pestisida, perubahan fisik tanah (tanah yang mengeras) sehingga berdampak pada saat pengolahan.

Berangkat dari kondisi demikian beberapa petani di lokasi penelitian mulai bermusyawarah untuk mencari solusi mengatasi permasalahan tersebut. Dari hasil diskusi maka diputuskan mereka melaksanakan kembali tehnik budidaya yang dilaksanakan dan diajarkan oleh para orang tua atau petani pendahulu mereka yaitu pupuk sintetis dosis penggunaannya dikurangi dan digantikan dengan sisa tumbuhan atau hewan ternak yang ada juga pestisida yang digunakan dibuat dari bahan - bahan alami. Penurunan produksi pada beberapa musim tanam terjadi akibat dari pengurangan penggunaan pupuk sintetis, pada tahun - tahun berikutnya dan sampai sekarang dimana sama sekali pupuk sintetis tidak digunakan produksi padi berada pada kondisi normal (sama seperti ketika menggunakan pupuk anorganik). Desa Sumber Ngepoh Kecamatan Lawang mempunyai daya dukung untuk melaksanakan pertanian organik di mana ketersediaan air yang ada berasal dari mata air yang belum tercemar oleh limbah industri maupun rumah tangga, dan ketersediaanya berlangsung sepanjang tahun, ketersediaan bahan - bahan pupuk dan pestisida organik sangat melimpah.

Pertanian organik dipahami sebagai suatu sistem produksi pertanamanyang berazaskan daur ulang hara secara hayati (Sutanto, 2002). Di Negara Indonesia sendiri perkembangan pertanian organik dimulai pada awal 1980-anyang ditandai dengan bertambahnya luas lahan pertanian organik, dan jumlahprodusen organik Indonesia dari tahun ke tahun. Berdasarkan data Lembaga Sertifikasi Pertanian Organik Indonesia (SPOI) yang diterbitkan oleh Aliansi OrganisIndonesia (AOI) tahun 2009, diketahui bahwa luas total area pertanian organik diIndonesia tahun 2009 adalah $231.687,11$ ha. Luas area tersebut meliputi luas lahanyang tersertifikasi, yaitu 97.351,60 ha (42 persen dari total luas area pertanianorganik di Indonesia) dan luas lahan yang masih dalam proses sertifikasi (pilotproject AOI), yaitu 132.764,85 ha (57 persen dari total luas area pertanian organikdi Indonesia). Luas total area pertanian organik tahun 2008 jauh lebih besardaripada tahun 2009, yaitu sekitar 235.078,16 ha. Sementara itu, total jumlahpelaku pertanian organik yang tercatat pada tahun 2009 adalah 12.101 produsenyang terdiri dari: 9.628 produsen tersertifikasi, sedangkan sisanya adalah 2.383produsen non sertifikasi, 80 produsen dalam proses sertifikasi, dan 10 produsenPAMOR (Penjaminan Mutu Organis Indonesia) yang merupakan salah satu bentuk sistem sertifikasi partisipasi.

Pertanian organik atau disebut sebagai sistem pertanian ramah lingkungan bukan merupakan hal baru di Indonesia, karena sebelum ada pupuk sintetis (buatan) para pendahulu pertanian hanya menggunakan bahan - bahan yang ada disekitar lingkungannya untuk dijadikan 
pupuk. Pergiliran tanaman dalam satu hamparan lahan juga sudah dilaksanakan sebagai salah satu pengendalian populasi hama dan penyakit. Di awal Abad 20 sistem pertanian dengan mengedepankan produksi yang sehat (organik) dengan teknik budidaya mengurangi atau bahkan menghilangkan sama sekali input luar (sintetis) sangat diminati oleh konsumen, sehingga sistem budidaya pertanian mengalami pergeseran dari yang hanya berorientasi mengejar angka produktivitas tinggi dengan mengabaikan kondisi lingkungan saat ini lebih mengarah kepada produktivitas tinggi akan tetapi ramah lingkungan dan sehat. Petani di lokasi penelitian (Desa Sumber Ngepoh Kecamatan Lawang) ketika pada awal peralihan sistem pertaniannya (dari konvensional ke organik) banyak mengalami kendala salah satunya adalah penurunan produksi sampai dengan $85 \%$ (hasil wawancara dengan Bapak Suroto sebagai salah satu penggagas dan pelaku usahatani padi organik di daerah penelitian) dan ketersedian input produksi . Sejauh mana analisa usahatani yang telah dilakukan oleh petani padi sawah organik dan anorganik, oleh sebab itu penelitian ini dilaksanakan.

Sudah banyak kajian atau penelitian tentang usahatani padi sawah organik, walaupun berbeda metode dan lokasi penelitian tetapi dihasil akhir menunjukkan bahwa usahatani padi sawah organik dari segi teknis maupun ekonomismenguntungkan, Rata-rata produktivitas usahatani padi yang menerapkan pertanian organik mandiri lebih tinggi dari produktivitas usahatani padi yang menerapkan pertanian konvensional. (Tien, 2009).

Tabel 1. Rata-Rata Produktivitas Lahan Usahatani Padi Berbagai Aplikasi Pertanian Organik dan Konvensional

\begin{tabular}{llllll}
\hline \multirow{2}{*}{ Musim Tanam } & \multicolumn{5}{c}{ Rerata Produksi/ha (kg GKP/ha) } \\
\cline { 2 - 6 } & OM & OTM & TOM & TOTM & C \\
\hline M K 1 & 6467.50 & 6278.57 & 6273.55 & 6074.61 & 5022.82 \\
M. K 2 & 6860.83 & 6955.95 & 6819.02 & 6504.87 & 5443.91 \\
M. H & 5728.33 & 5580.95 & 5489.02 & 5218.75 & 4559.96 \\
Rerata & 6352.22 & 6271.83 & 6193.86 & 5932.74 & 4965.07 \\
\hline
\end{tabular}

Sumber Tien (2009)

Keterangan $: \mathrm{OM}=$ Organik Mandiri $; \mathrm{OTM}=$ Organik Tidak Mandiri $; \mathrm{TOM}=$ Transisi Organik Mandiri ; TOTM = Transisi Organik Tidak Mandiri; $\mathrm{C}=$ Konvensional

Tabel 2. Pendapatan usahatani Padi Sawah Berbagai Aplikasi Pertanian Organik

\begin{tabular}{llllll}
\multirow{2}{*}{\multicolumn{1}{c}{ Uraian }} & \multicolumn{5}{c}{ Rerata Rupiah/ha } \\
\cline { 2 - 6 } & OM & OTM & TOM & TOTM & C \\
\hline Penerimaan & 15678083 & 15492857 & 14391378 & 13457160 & 10981470 \\
Biaya Finansial & 7713247 & 8551617 & 8975459 & 9462500 & 9225841 \\
Biaya Riil & 711910 & 798107 & 816022 & 865467 & 848327 \\
Pendapatan Finansial & 7964836 & 6941239 & 5415919 & 3994660 & 1755629 \\
Pendapatan Riil & 8558977 & 7511785 & 6231156 & 4802490 & 2498196 \\
\hline
\end{tabular}

Sumber Tien (2009)

Keterangan $: \mathrm{OM}=$ Organik Mandiri $; \mathrm{OTM}=$ Organik Tidak Mandiri $; \mathrm{TOM}=$ Transisi Organik Mandiri ; TOTM = Transisi Organik Tidak Mandiri; $\mathrm{C}=$ Konvensional

Keadaan tersebut terjadi pada seluruh musim tanamhal ini diharapkan ke depan mampu merubah paradigma pola fikir pelaku utama usahatani padi sawah 
dan penentu kebijakan pembangunan pertanian untuk tidak hanya mengejar capaian tingginya produktivitas tetapi juga memperhatikan kelestarian lingkungan dengan penggunaan High Eksternal Input Agricultural (HEIA) dapat hilang dengan sendirinya. Tjuan penelitian ini adalah : (1) Menganalisis usahatani : struktur biaya, benefit, pendapatan dan efisiensi usahatani bagi petani yang melaksanakan usahatani padi organik dan anorganik,

Membandingkan faktor-faktor Input produksi (Tenaga Kerja, Pupuk, Benih, dan pestisida) pada produksi usahatani padi Organik dan Anorganik.

\section{METODE PENELITIAN}

\section{Subjek, Objek, dan Tempat Penelitian}

Subjek penelitian adalah petani yang menjadi anggota kelompok tani Sumber Makmur I untuk pertanian organik dan Kelompok Tani Sumber Makmur III untuk Anorganik. Objek penelitian yaitu usahatani yang dilakukan kelompok dengan cara organik dan konvensional. Penetapan lokasi dilakukan secara sengaja (purposive),dengan pertimbangan bahwa kelompok tersebut merupakan salah satu kelompok tani di Jawa Timur yang telah melaksanakan pertanaman padi sawah secara organik yang telah memperoleh sertifikat sebagai produsen pangan organik dari Lembaga Sertifikasi Organik.

Waktu penelitian ini dilaksanakan mulai Bulan Agustus sampai dengan Oktober 2012 dimulai dengan penyusunan rencana, penyebaran kuesioner (data primer) dan penggalian data sekunder dari lembaga atau dinas terkait.

\section{Metode Penentuan Sampel}

\section{Disain Penelitian}

Penelitian ini bersifat survey mengambil sampel tertentu untuk mewakili jumlah populasi, dengan pendekatan diskriptif kuantitatif, deskriptif yaitu merepresentasikan hasil penelitian dengan data dalam tabel.

\section{Sumber Data dan Cara Menetukannya}

Ada 2 jenis data yang digunakan dalam penelitian ini :

Data Primer

Merupakan data yang diperoleh dengan cara melakukan wawancara kepada responden dengan menggunakan daftar pertanyaan (kuesioner) yang telah dipersiapkan sebelumnya agar data tersaji secara sistematis sehingga memudahkan dalam analisis datanya.

Data Sekunder

Data yang telah tersedia pada Lembaga atau Instansi terkait serta pada buku penunjang lainnya.

Cara pengambilan data melalui dua macam, yaitu :

1. Metode Wawancara

Adalah kegiatan mencari bahan (keterangan, pendapat) melalui tanya jawab lisan dengan siapa saja yang diperlukan. Wawancara diadakan untuk mengungkapkan latar belakang, motif-motif yang ada disekitar masalah yang diobservasi. (Soekartawi, 2006)

2. Metode Observasi

Dilakukan untuk mendapatkan berbagai fakta yang diperlukan. (Soekartawi, 2006)

\section{Populasi dan Metode Pengambilan Sampel}

Populasi yang digunakan dalam penelitian ini merupakan anggota kelompok tani yang melaksanakan Budidaya Padi sawah secara organik dan konvensional. Sampel penelitian sebanyak 30 orang dari masing - masing kelompoktani. Pengambilan sampel secara Stratified Simple Random Sampling,

\section{Metode Analisis}

\section{Analisis Usahatani}

Dalam melakukan analisis usahatani, seseorang dapat melakukannya menurut kepentingan untuk apa analisis usahatani yang dilakukannya. Dalam banyak pengalaman analisis usahatani yang dilakukan oleh petani atau produsen memang dimaksudkan untuk tujuan mengetahui atau meneliti (Soekartawi, dkk, 
1990), lebih lanjut beragam macam analisis yang dipilih tergantung pada tujuan yang ingin dicapai. Pada prakteknya, seringkali analisis usahatani dipilah menjadi analisis parsial dan analisis keseluruhan usahatani. Analisis parsial dilakukan pada satu cabang usahatani, sedangkan analisis keseluruhan usahatani dilakukan pada semua cabang usahatani (Soekartawi, 2002)

Dalam analisis usahatani, sering dilakukan dengan dua cara, yaitu : (a) Analisis Finansial, dan (b) Analisis Ekonomi (Soekartawi, 2006). Pada penelitian yang dilaksanakan dipilih analisis finansial untuk mengetahui data yang sebenarnya tentang usahatani dilokasi penelitian. Data dalam analisis finansial adalah data biaya yang riil dikeluarkan dalam proses produksi.

\section{Struktur Biaya}

Secara sistematis struktur biaya dituliskan dengan :

$T C=F C+V C$

Dimana :

TC = Total Cost

FC $=$ Fixed Cost

$\mathrm{VC}=$ Variabel Cost

\section{Struktur Penerimaan}

Penerimaan adalah jumlah nilai total output suatu usaha yang besarnya merupakan perkalian antara harga persatuan dengan jumlah total output atau dalam ekonomi perusahaan, penerimaan (revenue)adalah penerimaan produsen dari hasil penjualan outputnya. Boediono (1984) mengemukakan bahwa total revenue (TR) adalah perkalian antara produksi yang diperoleh petani dengan harga jual. Menurut Mubyarto (1989), penerimaan dapat berwujud tiga hal, yaitu : (a) Hasil penjualan tanaman atau produk yang dijual, (b) Produk yang dikonsumsi petani dan keluarganya selama melakukan kegiatan, dan (c) kenaikan nilai investasi yang dimiliki petani berubah setiap tahun.

Secara sistematis dihitung dengan memakai rumus :

$T R=P \times Q$

Dimana :

$T R=$ Total Revenue
$P \quad=$ Harga Jual padi $/ \mathrm{kw}$

$\mathrm{Q} \quad=$ jumlah produksi (dalam satuan $\mathrm{kw})$

\section{Struktur Pendapatan}

Menurut sohardjo dan Patong (1973), kegiatan usahatani merupakan kegiatan untuk memperoleh produksi dibidang pertanian. Pada akhirnya akan dinilai dari biaya yang dikeluarkan dari kegiatan usaha tani. Pendapatan usahatani merupakan bentuk imbalan jasa pengelola (petani), tenaga kerja keluarga dan modal yang dimiliki (termasuk lahan), yang diperoleh dari kegiatan - kegiatan diluar usahatani (Soekartawi, 1995).

Menurut Sutrisno

(1998), pendapatan adalah selisih atau beda dari nilai penerimaan usahatani dengan biaya yang dikeluarkan. Analisis pendapatan bagi seorang petani memberikan bantuan untuk mengukur apakah kegiatan usahanya untuk saat itu berhasil atau tidak. Secara sistematis dihitung dengan memakai rumus: $\pi=T R-T C$

Dimana :

$\pi=$ Pendapatan $/$ sekali musim tanam

$T R=$ Total Revenue (total Penerimaan) $T C=$ Total Cost $($ total biaya $)$

\section{Analisis R/C}

R/C adalah singkatan dari Return Cost Ratio atau dikenal sebagai perbandingan (nisbah) antara penerimaan dan biaya. Kelayakan/Efisiensi usahatani diukur berdasarkan nilai $\mathrm{R} / \mathrm{C}$ Ratio (revenue cost ratio), yaitu perbandingan antara penerimaan (revenue) dengan biaya (cost). Jika nilai R/C Ratio > 1 dapat dinyatakan bahwa usahatani efisien dan layak diusahakan karena diperoleh keuntungan, sebaliknya apabila nilai $R / C$ Ratio< 1 maka dinyatakan usahatani tidak efisien dan tidak layak untuk dilaksanakan. Jika nilai $R / C$ Ratio $=1$, dapat dinyatakan bahwa usaha tani bersifat impas, tidak diperoleh keuntungan tetapi juga tidak rugi (soekartawi, 1995)

Secara matematis dituliskan :

$$
\mathrm{a} \quad=\mathrm{R} / \mathrm{C}
$$$$
\mathrm{R} \quad=\mathrm{Py} . \mathrm{Y}
$$ 


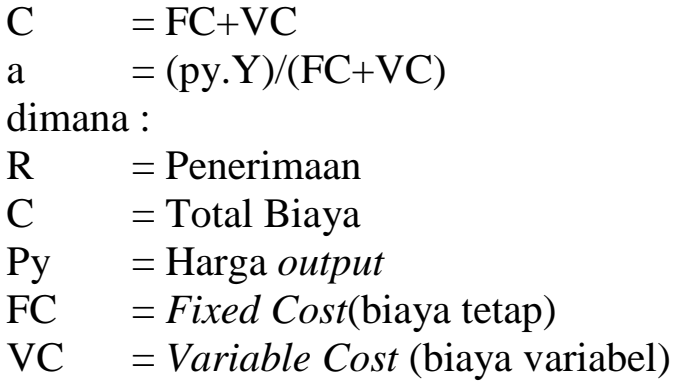

\section{Uji Chow Test dengan Dummy Variabel}

Menguji kesamaan-kesamaan koefisien dari dua sampel observasi untuk mengetahui signifikansi produksi dari usahatani Untuk menguji kesamaan koefisien-koefisien model regresi dari dua sampel observasi berbeda, Chow (1960) memformulasikan cara pengujian kesamaan koefisien-koefisien model regresi dari sampel observasi yang berbeda, dengan prosedur sebagai berikut:

a) Gabungkan observasi untuk $\mathrm{N}_{1}$ dan $\mathrm{N}_{2}$ dan lakukan regresi dengan data observasigabungan: $\mathrm{Y}=\alpha+\beta_{1} X_{1}+\ldots \ldots$. $\beta_{k} X_{\mathrm{k}}+\mu$. Dari regresi ini diperoleh nilai ResidualSum of Squares ( $\left.\mathrm{RSS}_{1}\right)$, dengan derajat bebas $=\mathrm{N}_{1}+\mathrm{N}_{2}-\mathrm{p}$.

b) Regresikan terpisah data observasi $\mathrm{N}_{1}$ dan $\mathrm{N}_{2}$, diperoleh nilai $\mathrm{RSS}_{2}$ dan $\mathrm{RSS}_{3}$ berderajat bebas $\mathrm{N}_{1}-\mathrm{p}$ dan $\mathrm{N}_{2}$ - $\mathrm{p}$. Peroleh $\mathrm{RSS}_{4}=\mathrm{RSS}_{2}+\mathrm{RSS}_{3}$ berderajat bebas $=\mathrm{N}_{1}+\mathrm{N}_{2}-2 \mathrm{p}$, kemudian hitung nilai $\mathrm{RSS}_{5}=\mathrm{RSS}_{1}$ $\mathrm{RSS}_{4}$

c) Gunakan $F_{\text {test }}$ dengan formulasi sebagai berikut :

$F_{\text {hit }}=$

$\frac{R S S S / P}{R S S 4 /(N 1+N 2-2 p)} \sim F \alpha(p, n 1+n 2-$

$2 p)$

Dalam regresi linear, variabel tak bebas (Y) dan variabel penjelas (X) bersifat bilangan atau kuantitatif, namun hal ini tidak selalu berlaku, ada kalanya variabel variabel penjelas bisa bersifat kualitatif, variabel kualitatif atau variabeldummy atau variabel boneka (dummy variable), punya beberapa istilah dalam literatur, seperti variabel indikator, variabel biner, variabel kategori dan variabel dikotomi. (Gujarati : 2006) Dalam hal ini variabel dummy digunakan untuk mengkodekan organik dengan 0 dan 1 untuk lainnya.

\section{HASIL DAN PEMBAHASAN}

\section{Keadaan Wilayah}

Luas Desa Sumber Ngepoh termasuk dalam Kecamatan Lawang Kabupaten Malang seluas 708 ha dengan rincian pada tabel berikut :

Tabel 4. Luas Desa dan Penggunaan Lahan

\begin{tabular}{lcc}
\hline Uraian & Luas (ha) & Prosentase (\%) \\
\hline Luas Desa & 708 & $100 \%$ \\
Sawah Irigasi Teknis & 35 & 4,430 \\
Sawah Irigasi Setengan Teknis & 85 & 12,46 \\
Tegal \& Kebun & 461,3 & 65,1 \\
Hutan konversi & 58 & 8,19 \\
Hutan Rakyat & 29,4 & 4,15 \\
Pemukiman & 35 & 5 \\
Fasilitas umum & 4,3 & 0,67 \\
\hline
\end{tabular}

Sumber : Data Primer diolah

\section{Sejarah Usahatani Padi Organik di Lokasi Penelitian}

Berawal dari keinginan beberapa orang di daerah penelitian pada tahun 1998 (era Reformasi) dimana mereka merasakan begitu tergantungnya kepada sarana produksi khususnya pupuk, ketersediannya sangat terbatas di pasar dan kalau ada harganya relatif mahal. Didasari hal tersebut maka beberapa orang yang di koordinir oleh Bapak Suroto mencoba melaksanakan budidaya padi sawah dengan menghilangkan input luar pada budidaya padi sawahnya. Diawal masa produksi 
terjadi penurunan produksi sampai dengan 85\% /hektarnya, sehingga beberapa orang mengusulkan untuk kembali pada sistem yang lama. Akan tetapi Bapak Suroto dengan kesadaran akan dampak yang ditimbulkan dari sistem pertanian konvensional (anorganik) tetap bertahan untuk melaksanakan budidayanya dengan sama sekali tidak menggunakan pupuk anorganik. Kegigihan dari Bapak Suroto ini dan dengan mengikuti pendidikan dan latihan yang dilaksanakan oleh lembaga atau dinas terkait, pada tahun kedua menunjukkan bahwa produksi padinya mengalami kenaikan walaupun belum sangat signifikan (berkisar sekitar 10-15\%). Karena menujukkan yang semakin meningkat sehingga memunculkan kembali keinginan dari beberapa orang untuk kembali mengikuti.

Pengembangan kelompok organik ini sangat didukung oleh sumber daya alam (SDA) khususnya pengairan, dimana lokasi budidaya padi sawah ini berdekatan dengan sumber mata air alami yang sudah dilaksanakan pengujian oleh lembaga terkait dengan hasil tidak tercemar. Ada tiga strata sistem budidaya padi sawah di kelompok tani di lokasi penelitian, yaitu :

1. Kelompok Tani Sumber Makmur I untuk pengembangan Budidaya padi sawah organik. Input Produksi yang digunakan (Pupuk, Benih dan Pestisida) sama sekali tidak menggunakan bahan anorganik

2. Kelompok Tani Sumber Makmur II untuk konversi pada pertanian organik (disebut sebagai semi organik). Input produksi yang digunakan $50 \%$ dari organik dan $50 \%$ dari anorganik

3. Kelompok Tani Sumber Makmur III Disebut sebagai sistem konvensional atau anorganik, karena input produksi yang digunakan $100 \%$ sintetis (buatan pabrik/perusahaan)

Untuk mengetahui produksi padi sawah organik ditahun 1998 (periode awal budidaya) sampai dengan tahun 2009 disajikan dalam tabel berikut:

Tabel 5. Produksi Riil Usahatani Padi Sawah Menuju Organik

\begin{tabular}{|c|c|c|c|}
\hline Tahun/MT & Luas (ha) & $\begin{array}{c}\text { Rata-rata Produksi } \\
\text { (kg) }\end{array}$ & Keterangan \\
\hline 1998 & & & $\begin{array}{llll}\text { Penggunan } & \text { Pupuk } & \text { Sintetis } & \text { masih }\end{array}$ \\
\hline MH & 1 & 2.920 & digunakan dengan konsentrasi $300-400$ \\
\hline MK I & & 2990 & $\mathrm{~kg} / \mathrm{ha}$, jerami dan pupuk kandang 5.000 \\
\hline MK II & & 3400 & $\mathrm{~kg} / \mathrm{ha}$ \\
\hline 1999 & & & Sintetis masih \\
\hline MH & 1 & 3510 & digunakan dengan konsentrasi $100-200$ \\
\hline MK I & & 3536 & $\mathrm{~kg} / \mathrm{ha}$, jerami dan pupuk kandang 5.000 \\
\hline MK II & & 3820 & $\mathrm{~kg} / \mathrm{ha}$ \\
\hline 2000 & & & Penggunan \\
\hline MH & 1 & 3750 & digunakan dengan konsentrasi $75-100$ \\
\hline MK I & & 3940 & $\mathrm{~kg} / \mathrm{ha}$, jerami dan pupuk kandang 5.000 \\
\hline MK II & & 4030 & $\mathrm{~kg} / \mathrm{ha}$ \\
\hline 2001 & & & Pupuk yang digunakan hanya pupuk \\
\hline MH & 1 & 3750 & kandang dan jerami, rata-rata $5.000 / \mathrm{ha}$ \\
\hline MK I & & 3940 & \\
\hline MK II & & 4300 & \\
\hline 2002 & & & Pupuk yang digunakan hanya pupuk \\
\hline $\mathrm{MH}$ & 1 & 5060 & kandang dan jerami, rata-rata $4.000 /$ ha \\
\hline MK I & & 5178 & \\
\hline MK II & & 5340 & \\
\hline 2003 & & & Pupuk yang digunakan hanya pupuk \\
\hline MH & 1 & 6674 & kandang dan jerami, rata-rata $3.500-$ \\
\hline MK I & & 6862 & $4.000 / \mathrm{ha}$ \\
\hline
\end{tabular}




\begin{tabular}{|c|c|c|}
\hline \multicolumn{3}{|l|}{ MK II } \\
\hline 2004 & & \\
\hline $\mathrm{MH}$ & \multirow[t]{2}{*}{1} & 7029 \\
\hline MK I & & 7360 \\
\hline MK II & & 7644 \\
\hline \multicolumn{3}{|l|}{2005} \\
\hline $\mathrm{MH}$ & \multirow[t]{4}{*}{1} & 7200 \\
\hline MK I & & 7690 \\
\hline MK II & & 7444 \\
\hline \multicolumn{2}{|l|}{2006} & \\
\hline $\mathrm{MH}$ & \multirow[t]{2}{*}{1} & 8650 \\
\hline MK I & & 8750 \\
\hline MK II & & 9100 \\
\hline \multicolumn{3}{|l|}{2007} \\
\hline $\mathrm{MH}$ & \multirow[t]{2}{*}{1} & 8650 \\
\hline MK I & & 8750 \\
\hline MK II & & 9100 \\
\hline \multicolumn{3}{|l|}{2008} \\
\hline $\mathrm{MH}$ & \multirow[t]{2}{*}{1} & 7200 \\
\hline MK I & & 7690 \\
\hline MK II & & 7444 \\
\hline \multicolumn{3}{|l|}{2009} \\
\hline $\mathrm{MH}$ & 1 & 8850 \\
\hline MK I & & 8910 \\
\hline MK II & & 9416 \\
\hline
\end{tabular}

Pupuk yang digunakan hanya pupuk kandang dan jerami, rata-rata 3.500/ha

Pupuk yang digunakan hanya pupuk kandang dan jerami, rata-rata 3.500/ha

Pupuk yang digunakan hanya pupuk kandang dan jerami, rata-rata 2.500/ha

Pupuk yang digunakan hanya pupuk kandang dan jerami, rata-rata 2.500/ha

Pupuk yang digunakan hanya pupuk kandang dan jerami, rata-rata 3.000/ha

Pupuk yang digunakan hanya pupuk kandang dan jerami, rata-rata 3.500/ha

Data primer diolah

Keterangan : MH = Musim Hujan; MK Musim Kemarau.

Dari data tabel diatas bahwa usahatani organik pelaksanaan sampai dengan tahun ke tiga masa produksi mengalami peningkatan produksi yang cukup signifikan, rata-rata mengalami peningkatan sebesar 10-15\%. Hasil ratarata produksi tertinggi dicapai pada saat $\begin{array}{llll}\text { Musim Kemarau II (MK } & \text { II). }\end{array}$

Karakteristik Responden Berdasarkan Pendidikan, Umur, Luas Lahan , Lama Usahatani, dan Status Kepemilikan Lahan Petani Padi Sawah Organik dan Anorganik.

Tabel 6. Distribusi Responden Padi organik dan Anorganik Berdasarkan Pendidikan,Umur, Rata-rata Luas Lahan, Rata-rata Lama Usahatani, Status Kepemilikan

\begin{tabular}{|c|c|c|c|c|c|}
\hline \multirow{2}{*}{ Uraian } & \multicolumn{2}{|c|}{ Organik } & \multicolumn{2}{|c|}{ Anorganik } & \multirow{2}{*}{ Keterangan } \\
\hline & Jml & $\%$ & Jml & $\%$ & \\
\hline \multicolumn{6}{|l|}{ Pendidikan : } \\
\hline 1. TTSD & 3 org & 10 & 0 & 0 & \\
\hline 2. SD & 20 org & 66,66 & 14 org & 46,66 & \\
\hline 3. SLTP & 5 org & 16,67 & 9 org & 30 & \\
\hline 4. SLTA & 2 org & 6,67 & 4 org & 10 & \\
\hline 5.PT & 0 & 0 & 3 org & 13,34 & \\
\hline Jumlah & 30 org & 100 & 30 org & 100 & \\
\hline \multicolumn{6}{|l|}{ Umur : } \\
\hline $40-50$ & 11 org & 36,67 & 20 org & 66,67 & \\
\hline $51-60$ & 17 org & 56,66 & 10 org & 33,33 & \\
\hline$>61$ & 2 org & 6,67 & 0 org & 0 & \\
\hline
\end{tabular}




$\begin{array}{lcccc}\text { Jumlah } & 30 \text { org } & 100 & 30 \text { org } & 100 \\ \text { Luas Lahan } & 14,7 & - & 23,5 & - \\ \text { Rata-rata } & 0,48 & & 0,76 & \\ \text { Lama Usahatani } & & & & \\ <20 \text { th } & 6 \text { org } & 20 & 0 & 0 \\ >\quad 20 \text { th } & 24 \text { org } & 80 & 30 \text { org } & 100 \\ \text { Jumlah } & 30 \text { org } & 100 & 30 \text { org } & 100 \\ \text { Status } & & & & \\ \text { Kepemilikan : } & 30 \text { org } & 100 & 30 \text { org } & 100 \\ \text { Pemilik } & 0 & 0 & 0 & 0 \\ \text { Lainnya } & 30 \text { org } & 100 & 30 \text { org } & 100 \\ \text { Jumlah } & & & & \end{array}$

Sumber :Data primer diolah

Keterangan : TTSD ; Tidak Tamat Sekolah Dasar; SD : Sekolah Dasar; SMP: Sekolah Menengah Pertama; SLTA : Sekolah Lanjutan Tingkat Atas; PT ; Perguruan Tinggi; Org ; orang

Dari data Sebaran distribusi responden berdasarkan pendidikan maka tingkat pendidikan Sekolah Dasar (SD) menempati prosentase tertinggi $(66,66 \%)$ untuk organik, anorganik 14 orang menempati prosentase tertinggi $(46,66 \%)$, diikuti yang Tidak Tamat Sekolah Dasar (TTSD) 3 orang $(10 \%)$ untuk oraganik, anorganik 0 , berikutnya tingkat pendidikan Sekolah Menengah Pertama (SLTP) 5 orang dengan prosentase 16,67, anorganik 9 orang menempati prosentase ke dua (30\%) dan yang terakhir ditempati oleh pendidikan Sekolah Lanjutan Tingkat Atas (SLTA) sebanyak 2 orang $(6,67 \%)$, anorganik untuk pendidikan SLTA sebanyak 4 orang $(10 \%)$ sedangkan untuk pendidikan Perguruan Tinggi untuk responden organik 0 dan anorganik sebanyak 3 orang $(13,34 \%$ dari jumlah responden). Data sebaran distribusi responden berdasarkan umur maka Responden yang melakukan aktivitas budidaya tanaman padi sawah organik ratarata berusia tua yaitu 17 orang (berusia diantara 50 - 60 tahun) dari responden sebanyak 30 orang $(56,66 \%)$, diikuti oleh usia produktif sebanyak 11 orang $(36,67 \%)$ dan, yang terakhir sebanyak 2 orang dari usia 61 tahun keatas $(6,67 \%)$, untuk anorganik $66,67 \%$ atau 20 orang dari jumlah responden berusia diantara 40- 50 tahun dan sisanya 10 orang $(33,33 \%$ dari jumlah responden) berusia diantara 51-60 tahun.

Dari pengalaman dalam berusahatani untuk pertanian organik sebanyak 6 orang kurang dari 20 tahun, 24 orang lebih dari 20 tahun, sedangkan pada petani anorganik dari 30 responden pengalaman dalam berusahatani lebih dari 20 tahun, data sebaran distribusi responden rata-rata luas lahan (sebelum dikonversi) petani anorganik lebih luas dibandingkan dengan pertanian organik, menurut data sebaran distribusi responden berdasarkan status kepemilikan lahan, semua responden yang menjadi sampel dalam penelitian adalah sebagai pemilik lahan

\section{Analisis Statistik Usahatani}

Rata - rata biaya, penerimaan, pendapatan dan efisiensi yang usahatani adalah

Tabel 7. Rata-rata Produksi , Total Biaya, Total Penerimaan, Pendapatan, dan Efisiensi UT Padi Sawah Organik dan Organik (konversi 1 ha)

\begin{tabular}{llcc}
\hline \multirow{2}{*}{ No. } & \multirow{2}{*}{ Uraian } & \multicolumn{2}{c}{ Jumlah } \\
& & Organik & Anorganik \\
\hline 1. & Produksi $(\mathrm{kw})$ & 79,87 & 79,84 \\
2. & Total Biaya $(\mathrm{Rp})$ & 6.953 .484 & 5.310 .150
\end{tabular}


3. Total Penerimaan (Rp)

4. Total Pendapatan (Rp)

5. RC Ratio
23.962 .853

17.009.369

3,43
21.557.082

16.439 .009

4,07
Sumber : Data primer 2014 diolah

Data tabel 5 menunjukkan bahwa produksi riil yang diperoleh petani (setelah dikonversi kedalam luasan 1 hektar) pada usahataninya dalam satuan kwintal (kw) terdapat selisih produksi antara organik dan anorganik yaitu berkisar antara 0,03 kwintal.

\section{a. Total biaya}

yang dikeluarkan dalan satu kali tanam sebesar Rp. 6. 953.484, terdiri ratarata pajak tanah yang dibayarkan pada 1 kali masa produksi, sebesar Rp. 65.085, rata-rata iuran pengairan yang dibayarkan pada setiap 1 kali masa produksi sebesar Rp. 100.000 , adalah rata - rata biaya sewa mesin perontok sebesar Rp. 798.762, ratarata sewa hand sprayer satu kali produksi Rp.29.804 , biaya selamatan rata-rata satu kali produksi Rp.674.020, biaya benih yang dikeluarkan satu kali produksi Rp. 210.984 dan rata - rata biaya pengolahan tanah dalam satu kali masa produksi ,1.336.601 rata-rata biaya tenaga kerja sebesar $\mathrm{Rp}$. 1.335.444, rata - rata biaya pupuk dalam satu kali masa produksi,Rp. 2.250.000, rata - rata biaya jerami, Rp. 489.386 dan ratarata biaya pestisida nabati yang dikeluarkan dalam satu kali masa produksi Rp. 1.000.000,- (organik).

Sedangkan untuk anorganik ratarata pajak tanah yang dibayarkan pada satu kali masa produksi,Rp. 55.399,- rata-rata iuran pengairan yang dibayarkan pada setiap satu kali masa produksi, Rp. 100.000 ,- rata-rata biaya sewa perontok satu kali produksi Rp.798.410, rata-rata biaya sewa hand sprayer satu kali produksi,Rp. 29.033,- rata-rata biaya selamatan satu kali produksi, Rp. 433.889, rata-rata biaya benih satu kali produksi Rp.329.778, rata-rata biaya pengolahan tanah satu kali produksi Rp.966.667, ratarata biaya tenaga kerja $\mathrm{Rp} .1 .236 .200$, ratarata input pupuk dalam satu kali masa produksi Rp.500.775, dan rata-rata biaya pestisida yang dikeluarkan dalam satu kali masa produksi Rp.810.000

\section{b. Total Penerimaan}

Jumlah penerimaan usahatani organik adalah sebesar Rp.Rp. 23.962.85, didapat dari perkalian antara jumlah produksi Gabah Kering Panen (GKP) dan harga jual, jumlah penerimaan tersebut lebih besarRp. 2.405.771,-- dibandingkan dengan anorganik, jumlah penerimaan anorganik sebesar Rp. 21.557.082. hal ini dapat dijelaskan bahwa terdapat selisih harga jual Gabah Kering Panen sebesar Rp. $30.000 / \mathrm{kw}$.

\section{c. Pendapatan $(\pi)$}

Adalah pengurangan dari total penerimaan dikurangi oleh total biaya, untuk pendapatan dari usahatani organik sebesar Rp. 17.009.369 dan usahatani anorganik sebesar Rp. 16.439.009,- terdapat selisih sebesar Rp. 570.360,- hal ini dapat dijelaskan bahwa harga jual dari produksi terdapat selisih. sebesar Rp.30.000,organik lebih tinggi

\section{d. $\mathbf{R} / \mathbf{C}$}

Dari perbandingan antara penerimaan dan biaya diperoleh nilai untuk organik sebesar 3,43, dan anorganik sebesar 4, 07, terdapat selisih 0,64 anorganik lebih tinggi. $\mathrm{R} / \mathrm{C}>1$ artinya bahwa kedua usahatani menguntungkan dan layak untuk diusahakan karena menguntungkan.

\section{Analisis Chow test}

Pada analisis ini, dilakukan dengan tujuan untuk menguji kesamaan koefisienkoefisien model regresi dari dua sampel observasi berbeda.

Langkah pertama meregresikan gabungan hasil observasi untuk mendapatkan nilai Residual Sum Of Square $1\left(R S S_{1}\right)$. 
Tabel 8. Hasil Analisis Regresi Berganda Usaha Tani Gabungan

\begin{tabular}{ccccc}
\hline Variabel & Koefisien regresi & T hitung & T tabel & Sig. \\
\hline Constant & 10,292 & 3,201 & & 0,002 \\
Tenaga Kerja & 0,384 & 1,163 & & 0,250 \\
Pupuk & $-0,005$ & $-6,922$ & \multirow{2}{*}{, 060} & 0,000 \\
Benih & 0,676 & 2,634 & & 0,011 \\
Pestisida & 1,610 & 4,675 & & 0,000 \\
Dummy (jenis usaha tani) & $-14,757$ & $-3,191$ & & 0,002 \\
F hitung & 147,026 & & & \\
F tabel & 2,759 & & & \\
Sig. F & 0,000 & & & \\
R $^{2}$ Adjusted & 0,925 & & & \\
\hline
\end{tabular}

$Y=10,292+0,384 X_{1}-0,005 X_{2}+0,676 X_{3}+1,610 X_{4}-14,757 D+e$

Uji F menjelaskan pengaruh tenaga kerja, pupuk, benih dan pestisida secara bersama-sama terhadap produksi. Diperoleh F hitung sebesar 147,026 dan $F$ tabel sebesar 2,759 pada taraf kepercayaan $95 \%$ $(\alpha=0,05)$. Karena $F$ hitung menunjukkan lebih besar dari $\mathrm{F}$ tabel sehingga dapat disimpulkan bahwa terdapat pengaruh yang signifikan antara tenaga kerja, pupuk, benih dan pestisida terhadap produksi secara bersama-sama.

Berikut ini akan dijelaskan pengaruh masing-masing variabel bebas terhadap produksi.

1. Tenaga Kerja

Hasil uji t menunjukkan bahwa tenaga kerja berpengaruh tidak nyata pada $\alpha=0,05$ karena $\mathrm{t}$ hitung lebih kecil dari $\mathrm{t}$ tabel $(1,163<2,060)$ pada taraf kepercayaan $95 \%$. Hal ini menunjukkan bahwa tenaga kerja berpengaruh tidak nyata terhadap produksi.

2. Pupuk

Berdasarkan hasil uji t menunjukkan bahwa penggunaan pupuk berpengaruh sangat nyata pada taraf kepercayaan $95 \%$ $(\alpha=0,05)$. Karena $t$ hitung lebih besar dari pada $t$ tabel $(6,922<2,060)$. Besaran elastisitas b2(-0,005) menunjukkan setiap penambahan 1 satuanpupuk akan mengakibatkan penurunan produksi sebesar 0,005 kali.

3. Benih

Berdasarkan hasil uji t menunjukkan bahwa penggunaan benih berpengaruh nyata pada taraf kepercayaan $95 \%$ $(\alpha=0,05)$. Karena $t$ hitung lebih besar dari pada t tabel $(2,634>2,060)$. Besaran elastisitas b3 $(0,676)$ menunjukkan setiap penambahan 1 satuanbenih akan menambah produksi sebesar 0,676 kali.

4. Pestisida

Berdasarkan hasil uji $\mathrm{t}$ menunjukkan bahwa penggunaan pestisida berpengaruh nyata pada taraf kepercayaan $95 \%(\alpha=0,05)$. Karena $t$ hitung lebih besar dari pada $\mathrm{t}$ tabel (4,675> 2,060). Besaran elastisitas b4(1,610) menunjukkan setiap penambahan 1 satuan pestisida akan memberikan tambahan produksi sebesar 1,610 kali.

5. Dummy (jenis usaha tani)

Berdasarkan hasil uji $t$ menunjukkan bahwa jenis usaha tani berpengaruh nyata pada taraf kepercayaan $95 \%(\alpha=0,05)$. Karena $t$ hitung lebih besar dari pada t tabel $(3,191>2,060)$. Besaran elastisitas b5(-14,757) menunjukkan bahwa jika jenis usaha tani adalah adalah anorganik $(\mathrm{D}=1)$, maka produksi akan menurun sebesar 14,757. Dan jika jenis usaha tani adalah organik $(\mathrm{D}=0)$ maka produksi akan tetap.

Langkah keduamelakukan regresi terpisah dari masing - masing observasi untuk mendapatkan Residual Sum of Square1 dan 2 (RSS $_{2}$ dan $\left.R S S_{3}\right)$ 
Tabel 9. Hasil Analisis Regresi Berganda Usaha Tani Anorganik

\begin{tabular}{ccccc}
\hline Variabel & Koefisien regresi & T hitung & T tabel & Sig. \\
\hline Constant & $-3,822$ & $-1,448$ & & 0,160 \\
Tenaga Kerja & $-1,148$ & $-2,924$ & & 0,007 \\
Pupuk & $-0,387$ & $-2,745$ & 2,060 & 0,011 \\
Benih & $-0,048$ & $-0,212$ & & 0,834 \\
Pestisida & 8,863 & 5,133 & & 0,000 \\
F hitung & 245,139 & & & \\
F tabel & 2,759 & & & \\
Sig. F & 0,000 & & & \\
R $^{2}$ Adjusted & 0,971 & &
\end{tabular}

Uji $\mathrm{F}$ menjelaskan pengaruh tenaga kerja, pupuk, benih dan pestisida secara bersama-sama terhadap produksi. Diperoleh F hitung sebesar 245,139 dan F tabel sebesar 2,759 pada taraf kepercayaan $95 \%$ $(\alpha=0,05)$. Karena $F$ hitung menunjukkan lebih besar dari $\mathrm{F}$ tabel sehingga dapat disimpulkan bahwa terdapat pengaruh yang signifikan antara tenaga kerja, pupuk, benih dan pestisida terhadap produksi secara bersama-sama.

Berikut ini akan dijelaskan pengaruh masing-masing variabel bebas terhadap produksi.

1. Tenaga Kerja

Hasil uji t menunjukkan bahwa tenaga kerja berpengaruh nyata pada $\alpha=0,05$ karena $\mathrm{t}$ hitung lebih besar dari t tabel $(2,924>2,060)$ pada taraf kepercayaan 95\%. Hal ini menunjukkan bahwa tenaga kerja berpengaruh sangat nyata terhadap produksi. Besaran elastisitas b1 $(-1,148)$ menunjukkan setiap penambahan tenaga kerja akan mengakibatkan berkurangnya produksi sebesar 1,148 kali.

2. Pupuk

Berdasarkan hasil uji t menunjukkan bahwa penggunaan pupuk berpengaruh nyata pada taraf kepercayaan $95 \%$ $(\alpha=0,05)$. Karena $t$ hitung lebih besar dari pada $t$ tabel $(2,745>2,060)$. Besaran elastisitas b2 (-0,387) menunjukkan setiap penambahan pupuk akan mengakibatkan berkurangnya produksi sebesar 0,387kali.

3. Benih

Berdasarkan hasil uji $\mathrm{t}$ menunjukkan bahwa penggunaan benihtidak berpengaruh nyata pada taraf kepercayaan $95 \%(\alpha=0,05)$. Karena $t$ hitung lebih kecil dari pada $\mathrm{t}$ tabel $(0,212<2,060)$.

4. Pestisida

Berdasarkan hasil uji $\mathrm{t}$ menunjukkan bahwa penggunaan pestisida berpengaruh sangat nyata pada taraf kepercayaan $95 \%(\alpha=0,05)$. Karena $t$ hitung lebih besar dari pada $\mathrm{t}$ tabel $(5,133>2,060)$. Hal ini menunjukkan bahwa penggunaan pestisida berpengaruh sangat nyata terhadap produksi. Besaran elastisitas b4 $(8,863)$ menunjukkan setiap penambahan 1 satuan pestisida akan memberikan tambahan produksi sebesar 8,863 kali. 
Tabel 10. Hasil Analisis Regresi Berganda Usaha Tani Organik

\begin{tabular}{ccccc}
\hline Variabel & Koefisien regresi & T hitung & T tabel & Sig. \\
\hline Constant & 12,945 & 5,087 & & 0,000 \\
Tenaga Kerja & $-0,766$ & $-0,775$ & & 0,446 \\
Pupuk & 0,005 & 0,394 & 2,060 & 0,697 \\
Benih & $-0,579$ & $-0,159$ & & 0,875 \\
Pestisida & 0,743 & 2,266 & & 0,032 \\
F hitung & 34,456 & & & \\
F tabel & 2,759 & & & \\
Sig. F & 0,000 & & & \\
R $^{2}$ Adjusted & 0,822 & & & \\
\hline
\end{tabular}

$\mathrm{Y}=12,945-0,766 \mathrm{X}_{1}+0,005 \mathrm{X}_{2}-0,579 \mathrm{X}_{3}+0,743 \mathrm{X}_{4}+\mathrm{e}$

Uji $\mathrm{F}$ menjelaskan pengaruh tenaga kerja, pupuk, benih dan pestisida secara bersama-sama terhadap produksi. Diperoleh F hitung sebesar 34,456 dan $\mathrm{F}$ tabel sebesar 2,759 pada taraf kepercayaan $95 \%$ $(\alpha=0,05)$. Karena $F$ hitung menunjukkan lebih besar dari $\mathrm{F}$ tabel sehingga dapat disimpulkan bahwa terdapat pengaruh yang signifikan antara tenaga kerja, pupuk, benih dan pestisida terhadap produksi secara bersama-sama.

Berikut ini akan dijelaskan pengaruh masing-masing variabel bebas terhadap produksi.

1. Tenaga Kerja

Hasil uji t menunjukkan bahwa tenaga kerja berpengaruh tidak nyata pada $\alpha=0,05$ karena $\mathrm{t}$ hitung lebih kecil dari $\mathrm{t}$ tabel $(0,775<2,060)$ pada taraf kepercayaan $95 \%$. Hal ini menunjukkan bahwa tenaga kerja berpengaruh tidak nyata terhadap produksi.

2. Pupuk

Berdasarkan hasil uji t menunjukkan bahwa penggunaan pupuk berpengaruh tidak nyata pada taraf kepercayaan $95 \%$ $(\alpha=0,05)$. Karena t hitung lebih kecil dari pada t tabel $(0,394<2,060)$.

3. Benih

Berdasarkan hasil uji $\mathrm{t}$ menunjukkan bahwa penggunaan benihtidak berpengaruh nyata pada taraf kepercayaan $95 \%(\alpha=0,05)$. Karena $t$ hitung lebih kecil dari pada $t$ tabel $(0,159<2,060)$.

4. Pestisida
Berdasarkan hasil uji $\mathrm{t}$ menunjukkan bahwa penggunaan pestisida berpengaruh nyata pada taraf kepercayaan $95 \%(\alpha=0,05)$. Karena $t$ hitung lebih besar dari pada $t$ tabel $(2,266>2,060)$. Hal ini menunjukkan bahwa penggunaan pestisida berpengaruh nyata terhadap produksi. Besaran elastisitas b4 (0,743) menunjukkan setiap penambahan 1 satuan pestisida akan memberikan tambahan produksi sebesar 0,743 kali.

\section{Analisis Chow test}

Pada analisis ini, dilakukan dengan tujuan untuk menguji kesamaan koefisienkoefisien model regresi dari dua sampel observasi berbeda.

1. Hasil regresi gabungan antara jenis usahatani organik dan anorganik menghasilkan nilai Residual Sum of Squares $\left(\mathrm{RSS}_{1}\right)$ sebesar 4443,431 dengan derajat bebas sebesar 56

2. Hasil regresi untuk jenis usahatani organik menghasilkan Residual Sum of Squares $\left(\mathrm{RSS}_{2}\right)$ sebesar 1131,893 dengan derajat bebas sebesar 26 .

3. Hasil regresi untuk jenis usahatani anorganik menghasilkan Residual Sum of Squares $\left(\mathrm{RSS}_{3}\right)$ sebesar 1167,170 dengan derajat bebas sebesar 26 .

4. Setelah itu, dihitung $\mathrm{RSS}_{4}$ yang diperoleh dengan menjumlahkan $\mathrm{RSS}_{2}$ dan $\operatorname{RSS}_{3}(1131,893+1167,170=$ 2299,063) dengan derajat bebas sebesar 52

5. Kemudian dihitung $\mathrm{RSS}_{5}$ yang diperoleh dari $\mathrm{RSS}_{1}$ dikurangi dengan 
$\mathrm{RSS}_{4}(4443,431-2299,063=$ 2144,368)

6. Langkah terakhir yaitu menghitung nilai Ftest dengan formulasi sebagai berikut:

$F_{\text {hit }}$
$\frac{R S S S / P}{R S S /(N 1+N 2-2 p)} \sim F \alpha(p, n 1+n 2-$
$2 p) \frac{2144,368 / 4}{2299.063 /(30+30-8)}$

$F_{\text {hit }}=12,125$

Ftabel $=2,550$

Karena $\mathrm{F}$ hitung > F tabel maka dapat disimpulkan bahwa model regresi jenis usaha tani organik dengan anorganik berbeda nyata atau dengan kata lain hasil produksi kedua jenis usaha tani yang dipengaruhi oleh faktor tenaga kerja, pupuk, benih dan penggunaan pestisida berbeda nyata.

\section{SIMPULAN DAN SARAN}

\section{Simpulan}

Kedua usahatani layak untuk diusahakan, tidak terdapat perbedaan yang sigifikan pada produksi, total biaya, penerimaan dan pendpatan.

Dari regresi usahatani faktor faktor yang paling mempengaruhi produksi diantara variabel Tenaga Kerja $\left(\mathrm{X}_{1}\right)$, Input Pupuk $\left(\mathrm{X}_{2}\right)$, Input Benih $\left(\mathrm{X}_{3}\right)$, dan Pestisida $\left(\mathrm{X}_{4}\right)$ keempat variabel secara signifikan berpengaruh nyata terhadap Produksi (Y) untuk anorrganik sedang pada organik dari ke empat variabel hanya pada Pestisida $\left(\mathrm{X}_{4}\right)$ berpengaruh sangat nyata terhadap produksi

\section{Saran}

1. Dalam pelaksanaan Budidaya padi sawah pendampingan dari kelembagaan sangat diperlukan, khususnya penggunaan pupuk harus menyesuaikan dengan kebutuhan unsur hara tanaman di lokasi tertentu.

2. Kegiatan Penyuluhan dan Pelatihan bagi petani padi sawah lebih ditingkatkan dengan model pendampingan untuk pencapaian salah satu dari Empat Sukses Pembangunan
"Swasembada Berkelanjutan"

3. Diperlukan penelitian-penelitian lanjutan secara komprehensif guna melihat perkembangan prospek budidaya padi organik, serta kemungkinannya didalam pencapaian sesuai dengan potensi hasil yang diharapkan

\section{DAFTAR PUSTAKA}

Arikunto, 2006. Prosedur Penelitian Suatu Pendekatan Praktik. Jakarta : PT Rineka Cipta

Gujarati, N Damodar (2006). Dasar-dasar Ekonometrika, Jakarta : Erlangga

Hernanto, F 1993. Ilmu Usahatani. Penebar Swadaya. Jakarta

Lumbantobing Rudolf, Disertasi . Studi Mengenai Perbedaan Struktur Modal Perusahaan Penanaman Modal Asing dengan Perusahaan Penanaman Dalam Negeri yang Go Public di Pasar Modal Indonesia

Mardikanto, T. 1994. Bunga Rampai Pembangunan Pertanian. UNS Press. Surakarta.

Mangunwidjaja, D dan Sailah, I. 2005. Pengantar Teknologi Pertanian. Penebar Swadaya. Depok.

Mardikanto, 2009. Sistem Penyuluhan Pertanian. Surakarta : UNS Press.

Norman Draper, Harry Smith, 1992. Analisi Regresi Terapan Edisi Kedua. Jakarta : PT Gramedia Pustaka Utama

Pujiharto (2009). Kajian Perilaku Petani Pembudidaya Tanaman Hortikultura dalam Konservasi Lahan Pada Zona Agroekologi (ZAE) Daerah Aliran sungai (DAS) Serayu Di Wilayah Kabupaten 
Banyumas. Agritech. Vol. XI No. 1 19-32.

Reintjes.1999. Pertanian Masa Depan. Kanisius Yogyakarta

Soekartawi, A. Sohardjo, John L. Dillon, J.

Brian Hardaker, 1986. Ilmu usahatani dan Penelitian Untuk Pengembangan Petani Kecil Jakarta : UI Press

Sutanto, R. 2002 Pertanian Organik. Kanisius Yogyakarta

Sokartawi, 2006. Analisis Usahatani. Jakarta :UI Press Swadaya. Jakarta

Suratiyah K, 2006. Ilmu Usahatani. Penebar Swadaya. Jakarta

Sugiyono, 2007. Statistika Untuk Penelitian. Bandung : Alfabeta
Sugiyono, 2007. Metode Penelitian Kuantitatif Kualitatif dan $R \& D$. Bandung : Alfabeta

Shinta, Agustina, 2011. Ilmu Usahatani. UB Press

Tien, (2011). Analisis Efisiensi Teknis Usahatani Padi Sawah Aplikasi Pertanian Organik, Jurnal Elhayah Vol. I, No. 4 Maret 2011

Taniredja, Mustafidah, (2011). Penelitian Kuantitatif Sebuah Pengantar. Bandung : Alfabeta

Usman, Akbar, 1996. Metodologi Penelitian Sosial. Jakarta : Bumi Aksara.

Wayan I, Mowidu Ita (2010). Perilaku Petani dalam Konservasi Lahan Pada Usahatani Kakao Di Kecamatan Poso Pesisir Utara. Media Litbang Sulteng III. No. 1 38-43. 